\title{
Enteric protein loss and intestinal permeability changes in children during acute shigellosis and after recovery: effect of zinc supplementation
}

\author{
A N Alam, S A Sarker, M A Wahed, M Khatun, M M Rahaman
}

\begin{abstract}
The effect of zinc supplementation on intestinal permeability changes and protein loss was studied in 32 children aged between 1 and 12 years during bouts of acute shigellosis and after recovery. An intestinal permeability test and then a 48 hour balance study were performed on all patients. They were then blindly assigned to receive vitamin $B$ syrup either with or without zinc acetate ( $15 \mathrm{mg} / \mathrm{kg}$ per day) for a month. All patients received a five day course of nalidixic acid. The balance study was repeated during convalescence and follow up, but a permeability test was done only at follow up after one month. Intestinal permeability, expressed as a urinary lactulose:mannitol excretion ratio, improved significantly $(p=0.001)$ along with a significant increase $(p=0.005)$ in mannitol excretion in the zinc supplemented children, suggesting a resolution of small bowel mucosal damage. The latter was associated with a higher coefficient of nitrogen absorption $(p=0.03)$, suggesting a possible role of zinc in the treatment of shigellosis. Enteric protein loss, as assessed by faecal $\alpha_{1}$ antitrypsin clearance, was not influenced by zinc supplementation.
\end{abstract}

(Gut 1994; 35: 1707-1711)

Shigellosis is still a major cause of morbidity and mortality, particularly among younger children in developing countries. In one recent study, there was an abnormal transmucosal protein loss in many of these patients. ${ }^{1}$ The pathological changes are confined to the colon and are characterised by erythematous and oedematus friable mucosa covered with an adherent mucopurulent layer. ${ }^{2}$ These changes result in loss of mucus and blood along with serum protein, and may continue even during the recovery period. ${ }^{3}$ Absorption of nitrogen compared to absorption of other nutrients was minimum in acute shigellosis. ${ }^{4}$ However, it could not be determined conclusively if the unabsorbed amount of nitrogen was related to protein loss other than failure of intestinal absorption. Intestinal permeability changes reflecting the integrity of the small intestinal mucosa have been reported in both acute $e^{5}$ and persistent diarrhoea. ${ }^{6}$ The extent and duration of enteric protein loss and its possible association with changes in intestinal permeability have, to our knowledge, not yet been studied in shigellosis. A metabolic balance study was therefore conducted together with determination of faecal clearance of $\alpha_{1}$ antitrypsin (an indirect measure of enteric protein loss) and excretion of lactulose and mannitol in children with shigellosis.

Zinc is a micronutrient that is commonly deficient in children in developing countries. Loss of zinc occurs in infants with acute diarrhoea. ${ }^{7}$ Furthermore, hypozincaemia and low rectal mucosal zinc concentrations have been shown in cases of childhood chronic diarrhoea, 89 although it was not clear whether the mucosal injury associated with these conditions resulted in such a loss. Zinc supplementation in patients with diarrhoea has been shown, however, to improve the mucosal integrity and is associated with significant reduction in diarrhoea attack rates, duration of diarrhoea, and stool volume, particularly when the patients are undernourished. ${ }^{6}$ The present study also aimed to explore the inter-relationship between gut permeability changes and enteric protein loss and to determine if zinc supplementation affects these changes.

\section{Methods}

Forty three boys and girls aged 1-12 years with a history of bloody mucoid diarrhoea of less than three days' duration were initially enrolled in the study. Microscopic examination of the stools of these patients suggested shigellosis. ${ }^{10}$ Children with obvious systemic illness - for example, pneumonia, meningitis, leukaemoid reaction, ${ }^{11}$ severe malnutrition $(<65 \%$ weight for age according to the National Center for Health Statistics), otitis media, and distension of the abdomen - were excluded from the study. All the patients had a detailed clinical examination on admission to hospital. Rectal swabs and stool samples were obtained from each patient on admission and were plated on MacConkey agar, SalmonellaShigella agar, and taurocholate-telluritegelatin agar. The plates were examined for Salmonella and Shigella by standard methods. ${ }^{12}$

TABLE I Composition of study diet (per $100 \mathrm{~g}$ )

\begin{tabular}{|c|c|c|c|}
\hline Name of food & $\begin{array}{l}\text { Protein } \\
(\mathrm{g} / 100 \mathrm{~g})\end{array}$ & $\begin{array}{l}\text { Zinc content } \\
(\mathrm{mg} / 100 \mathrm{~g})\end{array}$ & $\begin{array}{l}\text { Energy } \\
(\text { kcal/100 g) }\end{array}$ \\
\hline Milk suji & $2 \cdot 09$ & 0.23 & $92 \cdot 7$ \\
\hline Bread & $7 \cdot 44$ & $0 \cdot 10$ & $267 \cdot 5$ \\
\hline Egg (whole) & $12 \cdot 31$ & $1 \cdot 26$ & $160 \cdot 4$ \\
\hline Egg yolk & $14 \cdot 25$ & 4.00 & $436 \cdot 5$ \\
\hline Albumin (egg) & 14.56 & - & $105 \cdot 3$ \\
\hline Banana & $1 \cdot 81$ & $0 \cdot 14$ & $124 \cdot 0$ \\
\hline Rice & $2 \cdot 12$ & 0.33 & $120 \cdot 0$ \\
\hline Chicken curry & $14 \cdot 26$ & 0.72 & $296 \cdot 7$ \\
\hline Breast milk & 1.0 & 0.03 & $56 \cdot 2$ \\
\hline
\end{tabular}

\author{
Dr A N Alam, International \\ Centre for Diarrhoeal \\ Disease Research, \\ Bangladesh, \\ Dhaka 1000, Bangladesh. \\ Accepted for publication \\ 23 March 1994 \\ for Diarrhoeal \\ A N Alam \\ S A Sarker \\ M A Wahed \\ $M$ Khatun
}

(3) 
TABLE II Characteristics of study patients at the time of admission to hospital with shigellosis (values mean (SD))

\begin{tabular}{lll}
\hline & $\begin{array}{l}\text { Group I } \\
\text { (zinc } \\
\text { supplement) } \\
(n=16)\end{array}$ & $\begin{array}{l}\text { Group II } \\
\text { (no zinc } \\
\text { supplement) } \\
(n=16)\end{array}$ \\
\hline Age (mth) & $62(34)$ & $63(31)$ \\
Boy/girl & $13 / 3$ & $12 / 4$ \\
Duration of diarrhoea (d) & $6 \cdot 0(2 \cdot 0)$ & $5 \cdot 0(2 \cdot 1)$ \\
Duration of fever (d) & $6 \cdot 0(2 \cdot 0)$ & $5 \cdot 0(2 \cdot 1)$ \\
Packed cell volume (\%) & $36 \cdot 5(6 \cdot 3)$ & $37 \cdot 7(4 \cdot 9)$ \\
\% Weight for age (NCHS) & $76 \cdot 2(13 \cdot 0)$ & $73 \cdot 7(8 \cdot 5)$ \\
\% Weight for height (NCHS) & $88 \cdot 6(10 \cdot 5)$ & $88 \cdot 5(6 \cdot 0)$ \\
\% Height for age (NCHS) & $91 \cdot 5(8 \cdot 1)$ & $91 \cdot 6(5 \cdot 2)$ \\
Shigella species isolated: & & 6 \\
S flexneri & 8 & 8 \\
S dysenteriae & 7 & 1 \\
S boydii & 1 & 1 \\
S sonnei & - & \\
\hline
\end{tabular}

NCHS $=$ National Center for Health Statistics.

Shigella isolates were then biochemically identified and serotyped by a slide agglutination test using commercially available antisera (Burroughs Wellcome Research, Triangle Park, North Caroline, USA). Written, informed consent was obtained from parents or guardians before children were included in the study. The study was approved by the Human Ethical Review Committee of the International Centre for Diarrhoeal Disease Research, Bangladesh.

An intestinal permeability test using a freshly prepared solution containing $5 \mathrm{~g}$ lactulose with $0.5 \mathrm{~g}$ lactose $(7.5 \mathrm{ml}$ of Duphalac, Duphar Labs, Southampton, UK) and $1 \mathrm{~g}$ mannitol made up to $20 \mathrm{ml}$ with $1 \%$ chloroform water was performed using the method described by Behrens et al, ${ }^{13}$ starting soon after admission when rehydration had been accomplished. All patients were hydrated and were made to empty their bladder before the test dose was offered. Adhesive paediatric urine bags (Downs Ltd, London, UK) containing a drop of $20 \%$ ( $\mathrm{vol} / \mathrm{vol})$ chlorhexidine gluconate to prevent bacterial degradation of the probes were applied to the clean perineum to collect all urine samples over the next five hour period for subsequent measurement of the markers by an automated enzyme assay using Cobas-bio (Switzerland).

After this test, two charcoal tablets $(500 \mathrm{mg}$,

TABLE III Laboratory parameters on admission to hospital and after zinc supplementation in two groups of children with shigellosis and healthy controls (values, mean (SD))

\begin{tabular}{|c|c|c|c|c|}
\hline & $\begin{array}{l}\text { Group I } \\
\text { (zinc supplement) } \\
(n=16)\end{array}$ & $\begin{array}{l}\text { Group II } \\
\text { (no zinc supplement) } \\
(n=16)\end{array}$ & $p$ value & $\begin{array}{l}\text { Healthy } \\
\text { control }\end{array}$ \\
\hline \multicolumn{5}{|c|}{ Serum zinc $(\mu \mathrm{mol} / \mathrm{l})$ : } \\
\hline Admission & $11 \cdot 8(3.9)$ & $11 \cdot 2(2 \cdot 8)$ & $0 \cdot 60$ & \multirow{3}{*}{$\begin{array}{c}11 \cdot 8(2 \cdot 4) \\
\mathrm{n}=30\end{array}$} \\
\hline Day 8 & $13.9(3.5)$ & $11 \cdot 2(2 \cdot 4)$ & 0.01 & \\
\hline Day 30 & $12 \cdot 0(2 \cdot 2)$ & $11 \cdot 7(2 \cdot 1)$ & $0 \cdot 15$ & \\
\hline \multicolumn{5}{|c|}{ Serum protein $(g / 1)$ : } \\
\hline Admission & $67 \cdot 1(7 \cdot 4)$ & $67 \cdot 7(6 \cdot 3)$ & $0 \cdot 81$ & \multirow{3}{*}{$\begin{array}{c}70 \cdot 2(4 \cdot 2) \\
\mathrm{n}=150\end{array}$} \\
\hline Day 8 & $69 \cdot 3(8 \cdot 5)$ & $71 \cdot 1(4 \cdot 9)$ & 0.48 & \\
\hline Day 30 & $73 \cdot 1(6 \cdot 1)$ & $72 \cdot 3(6 \cdot 2)$ & $0 \cdot 73$ & \\
\hline \multicolumn{5}{|c|}{ Serum albumin $(g / l)$ : } \\
\hline Admission & $45 \cdot 5(4 \cdot 3)$ & $44 \cdot 7(3 \cdot 8)$ & 0.55 & \multirow{3}{*}{$\begin{array}{c}42 \cdot 5(2 \cdot 8) \\
\mathrm{n}=150\end{array}$} \\
\hline Day 8 & $42.9(5.9)$ & $42 \cdot 3(5 \cdot 3)$ & $0 \cdot 76$ & \\
\hline Day 30 & $47 \cdot 6(5 \cdot 3)$ & $46 \cdot 7(3 \cdot 7)$ & 0.99 & \\
\hline \multicolumn{5}{|c|}{ Serum alkaline phosphatase (IU): } \\
\hline Admission & $60.9(20.8)$ & $58 \cdot 6(15 \cdot 6)$ & 0.73 & \multirow{2}{*}{$\begin{array}{c}86 \cdot 0(20 \cdot 4) \\
n=150\end{array}$} \\
\hline $\begin{array}{l}\text { Day } 8 \\
\text { Day } 30\end{array}$ & $\begin{array}{l}69.2(10.2) \\
88.3(10.2)\end{array}$ & $\begin{array}{l}45 \cdot 5(14 \cdot 7) \\
68 \cdot 3(15 \cdot 2)\end{array}$ & $\begin{array}{l}0.05 \\
0.11\end{array}$ & \\
\hline \multicolumn{5}{|c|}{ Serum $\alpha_{1}$ antitrypsin $(\mathrm{mg} / \mathrm{dl})$ : } \\
\hline Admission & $333 \cdot 2(106 \cdot 7)$ & $331.5(101.9)$ & 0.56 & \multirow{3}{*}{$\begin{array}{c}127 \cdot 9(46 \cdot 3) \\
n=50\end{array}$} \\
\hline Day 8 & $285.5(94 \cdot 8)$ & $297.7(95.4)$ & 0.22 & \\
\hline Day 30 & $256.8(88 \cdot 7)$ & $267 \cdot 3(85 \cdot 9)$ & 0.96 & \\
\hline
\end{tabular}

homogenised in $15 \mathrm{ml}$ water) were given orally. Once the charcoal marker had appeared in the stool and the patients were clinically settled after full rehydration, a 48 hour balance study (first balance study), as previously described, ${ }^{4}$ was begun with a diet of known compositions (Table I). Food was weighed to an accuracy of $0 \cdot 1 \mathrm{~g}$ on a Toledo scale (Ohaus, Dial $\mathrm{Og}$ ) and was offered freely. The amounts offered and left over were measured and the difference was recorded as the amount consumed. None of our patients was breast fed. All patients received nalidixic acid (55 $\mathrm{mg} / \mathrm{kg}$ per day in four divided doses for five days), as Shigella species isolated from their stools or rectal swabs, or both, were sensitive to nalidixic acid. In a randomised, double blind manner, patients were also assigned to receive a vitamin $B$ preparation $\left(B_{1} 1,2 \mathrm{mg}\right.$, riboflavin $3.0 \mathrm{mg}$, nicotinamide $6.0 \mathrm{mg}, \mathrm{B}_{6} 0.6 \mathrm{mg}$, and calcium D-pathothenate $6.0 \mathrm{mg}$ in $5 \mathrm{ml}$ ) either with or without zinc acetate $(15 \mathrm{mg} / \mathrm{kg}$ per day with an elemental zinc of $3.9 \mathrm{mg} / \mathrm{kg}$ per day) given in three divided doses. The preparations were provided in suspensions that were identical in flavour, consistency, and appearance. It is well known that the requirement for zinc changes with age and that the availability of zinc from diets varies widely. Recommendations for the daily requirement of zinc range from 5.5 to $22 \mathrm{mg}$ daily. A predominantly cereal-legume-vegetable-based diet containing phytates and, possibly, other chelating substances in the study population, presence of undernutrition, and increased losses of zinc in the diarrhoea stool and sweat led us to use a larger amount of zinc to replace the perceived deficit in zinc status. The mean dietary zinc intakes were $0.300 \mathrm{mg} / \mathrm{kg}$ per day and $0.285 \mathrm{mg} / \mathrm{kg}$ per day in the supplemented and the unsupplemented groups respectively. A second 48 hour balance study was performed on day eight at the end of the nalidixic acid therapy. Patients were discharged from hospital and asked to continue the zinc/ placebo suspension at home for a further period of three weeks and then return for follow up testing. A permeability test was then repeated and a third balance study was performed. Transit time was measured as the time interval between feeding the charcoal marker and its first appearance in the stool during the three balance studies.

On admission to hospital and on day 8, venous blood was obtained for a complete blood count and estimation of serum electrolytes, creatinine, total protein, albumin, alkaline phosphatase, serum zinc, and serum $\alpha_{1}$ antitrypsin levels. Another blood sample was taken on day 30 to repeat the measurements of serum zinc, alkaline phosphatase, serum $\alpha_{1}$ antitrypsin, total protein, and albumin.

Total protein was estimated as total solids using a refractometer (American Optics Co), albumin by a modified colourimetric method ${ }^{14}$ using a spectrophotometer, and alkaline phosphatase was estimated using a commercial (BDH) kit. ${ }^{15}$

Serum zinc concentration was estimated 
TABLE IV Intestinal permeability changes in shigella patients on admission to hospital (day 1) and after four weeks of zinc supplementation (day 30) (geometric mean and 95\% confidence interval of $\%$ excretion)

\begin{tabular}{|c|c|c|c|}
\hline $\begin{array}{l}\text { Permeability probes } \\
(n=16)\end{array}$ & Day 1 & Day 30 & $\begin{array}{l}\text { Statistical } \\
\text { significance }\end{array}$ \\
\hline \multicolumn{4}{|l|}{ Lactulose: } \\
\hline Zinc supplement & $0.41(0.23-0.73)$ & $0.27(0.18-0.43)$ & NS \\
\hline No zinc supplement & $0.47(0.32-0.70)$ & $0.33(0.19-0.58)$ & NS \\
\hline \multicolumn{4}{|l|}{ Mannitol: } \\
\hline Zinc supplement & $1.36(0.85-2 \cdot 20)$ & $2 \cdot 71(1.53-4 \cdot 8)$ & $<0.005$ \\
\hline No zinc supplement & $1.15(0.71-1 \cdot 89)$ & $1.32(0.52-3.31)$ & NS \\
\hline \multicolumn{4}{|l|}{ LM ratio: } \\
\hline Zinc supplement & $0.30(0.16-0.52)$ & $0.09(0.08-0.14)$ & $<0.001$ \\
\hline No zinc supplement & $0.40(0.24-0.68)$ & $0.25(0.14-0.46)$ & NS \\
\hline
\end{tabular}

with an atomic absorption spectrophotometer (Pye Unicam SP9) as described by Smith et $a l,{ }^{16}$ and the serum and faecal concentrations of $\alpha_{1}$ antitrypsin were estimated as described by Crossley and Elliott. ${ }^{17}$ Faecal nitrogen content was measured according to the Micro-Kjeldahl procedure. ${ }^{18}$ The coefficient of absorption of $\mathrm{N}_{2}$ was calculated using the following formula:

$$
\text { Coefficient of } \mathrm{N}_{2} \text { absorption } \%=\frac{\mathrm{N}_{2} \text { intake }-\mathrm{N}_{2} \text { output }}{\text { Intake of } \mathrm{N}_{2}} \times 100
$$

Faecal clearance of $\alpha_{1}$ antitrypsin was calculated $^{3}$ using the formula shown below:

$$
\mathrm{C}=\frac{\mathrm{F} \times \mathrm{W}}{\mathrm{P}} \mathrm{ml} / \mathrm{d}
$$

Where $\mathrm{C}=$ faecal clearance of $\alpha_{1}$ antitrypsin, expressed as $\mathrm{ml}$ serum $/ \mathrm{d} ; \mathrm{F}=$ faecal concentration of $\alpha_{1}$ antitrypsin (mg/g); W = daily faecal weight ( $(\mathrm{g})$; and $\mathrm{P}=$ serum concentration of $\alpha_{1}$ antitrypsin $(\mathrm{mg} \%)$.

\section{STATISTICAL ANALYSIS}

The Student's $t$ test was used to compare the mean values of the two study groups when the distribution of data was normal. Data on intestinal permeability tests for both groups that were not normally distributed were log transformed before statistical analysis, and the anti-log was expressed as the geometric mean, with $95 \%$ confidence interval. The Student's paired $t$ test was done for comparison of two data points among the same group of subjects.

\section{Results}

Only 32 of the 43 patients were eligible for analysis, since the cultures of stool samples or rectal swabs were negative for Shigella species in the remaining 11 patients. Admission characteristics (Table II) of the study patients in the two groups were comparable. Table III presents the laboratory findings in the study patients. The serum total protein and albumin

TABLE V Faecal clearance of $\alpha_{1}$ antitrypsin ( $\mathrm{ml} / \mathrm{d}$ ) in shigellosis patients with or without zinc supplementation (values are median (range))

\begin{tabular}{llll}
\hline $\begin{array}{l}\text { 48 h balance } \\
\text { study }\end{array}$ & $\begin{array}{l}\text { Group I } \\
\text { (zinc supplement) } \\
(n=16)\end{array}$ & $\begin{array}{l}\text { Group II } \\
\text { (no zinc supplement) } \\
(n=16)\end{array}$ & $\begin{array}{l}\text { Statistical } \\
\text { significance }\end{array}$ \\
\hline Study 1 (day 1) & $161 \cdot 0(4 \cdot 0-753 \cdot 3)$ & $160 \cdot 0(9 \cdot 2-604 \cdot 3)$ & NS \\
Study 2 (day 8) & $59 \cdot 0(6 \cdot 0-160 \cdot 3)$ & $35 \cdot 1(9 \cdot 2-130 \cdot 4)$ & NS \\
Study 3 (day 30) & $57 \cdot 0(10 \cdot 0-109 \cdot 0)$ & $27 \cdot 0(3 \cdot 2-170 \cdot 1)$ & NS \\
\hline
\end{tabular}

concentrations improved in both groups of patients with clinical recovery. The mean serum zinc concentration and alkaline phosphatase activity increased significantly in the zinc supplemented group on day 8 during the second balance study and these changes maintained a similar trend during recovery (third balance study). Alkaline phosphatase accurately reflected total body zinc status ${ }^{19}$ in the study patients - activity decreased with zinc deficiency and significantly increased with zinc supplementation. Serum $\alpha_{1}$ antitrypsin was raised in both study groups in the acute stage, but decreased during clinical recovery. The mean duration of diarrhoea after hospital admission was shorter and the mean cumulative stool volume during hospitalisation was lower in the zinc supplemented group (137 v 146 hours and $28 v 31 \mathrm{gm} / \mathrm{kg}$ per day), but the differences were not significant. Children in both groups made similar gains in height and weight.

The effect of zinc supplementation on intestinal mucosal permeability is presented in Table IV. On admission day, no differences in probe markers between the study groups were observed. Lactulose excretion decreased after four weeks in both the groups, being more marked in the supplemented group. In the latter group, there was significant increase in mannitol excretion $(p=0.005)$ at follow up. As a result, the lactulose:mannitol ratio improved significantly $(p=0.001)$ towards normal value(s) in this group (analysis of variance was done with two way interaction terms including syrup and day, which was found to be statistically significant at $10 \%$ level). On the contrary, no such improvement was noticed in the unsupplemented group. An increased faecal clearance of $\alpha_{1}$ antitrypsin was observed (Table V) in both study groups during the first balance period (acute stage). These values decreased significantly in both groups during the early convalescent and after recovery but failed to attain normal values of less than 20 $\mathrm{ml} / \mathrm{d}^{320}$ in either group. Between the two groups, no difference in the faecal clearance of $\alpha_{1}$ antitrypsin was observed during the three balance periods. Total energy and nitrogen intake during the balance periods, as well as total nitrogen loss in stool, urine, and vomitus, were similar in the two study groups. The mean transit time varied from $8 \cdot 2$ to 9.3 hours during the acute stage, 10.6 to 13.2 hours during the convalescent period, and 16.7 to 19.9 hours after recovery in the zinc supplemented group. In the other study group, transit time varied from $9 \cdot 3$ to $11 \cdot 4$ hours, $11 \cdot 7$ to $16 \cdot 5$ hours, and $14 \cdot 1$ to $16 \cdot 2$ hours during the three stages of illness. The increase in transit time from acute to the recovery stage was significant $(p=0.01)$ in both the study groups. No significant relationship was, however, found between the transit time and coefficient of nitrogen absorption or between the transit time and urinary mannitol excretion during any stage of the illness. During the second balance period, nitrogen intake was marginally higher in the supplemented group (Table VI) with significant improvement in the 
TABLE VI Nitrogen absorption and balance in children with shigellosis supplemented (group 1) or not (group II) with zinc (values are mean (SD))

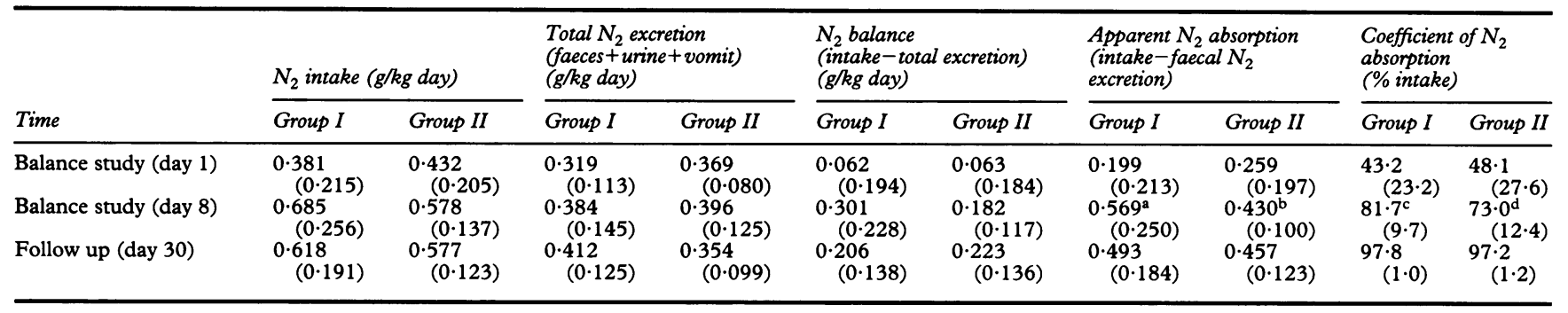

Significance of difference between the groups I (with zinc) and II (without zinc). a $v \mathrm{~b}, \mathrm{p}<0.04 ; \mathrm{c} v \mathrm{~d}, \mathrm{p}<0.03$.

apparent nitrogen absorption $(p=0 \cdot 04)$. The coefficients of nitrogen absorption were similar during the first (acute) balance period in both study groups, and it was significantly better $(p=0.03)$ in the zinc supplemented group during the second balance period. This differential effect was not maintained after recovery, however, when nitrogen absorption returned towards normal levels in both groups. Overall, a significant negative correlation $(\mathrm{r}=-0.52, \mathrm{p}=0.001)$ was observed (Figure) between nitrogen absorption and faecal clearance of $\alpha_{1}$ antitrypsin.

\section{Discussion}

The results of the study show that zinc plays an important part in intestinal mucosal regeneration and in the improvement of mucosal function. Higher lactulose and lower mannitol excretion with a higher lactulose:mannitol ratio in the study patients at hospital admission, compared with healthy Bangladeshi children ${ }^{6}$ suggested the presence of intestinal mucosal damage in shigellosis. It is well known that zinc repletion hastens regeneration of the damaged gut epithelium since zinc is essential for DNA, RNA, and protein synthesis. ${ }^{21} \mathrm{~A}$ significant increase in mannitol excretion with improvement in the lactulose:mannitol ratio after recovery, as was observed only in the supplemented group, suggests improved absorptive function after zinc supplementation. Lactulose excretion was, however, reduced in both study groups. Similar observations have been made $^{6}$ in

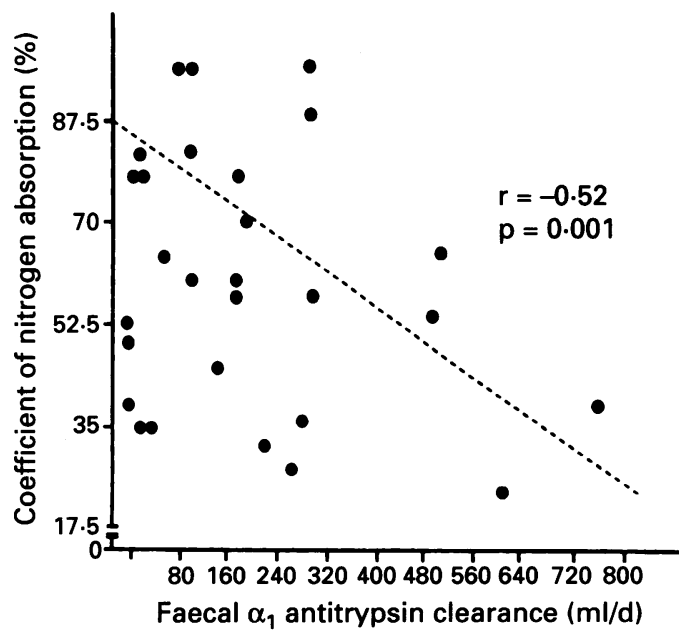

Faecal $\alpha_{1}$ antitrypsin clearance compared with coefficient of nitrogen absorption diarrhoea of other aetiologies. The improved absorptive mucosal function allowed significantly better nitrogen absorption in the zinc supplemented group during the convalescent period. Permeability tests done simultaneously would have further clarified the role of zinc in shigellosis. This was an obvious limitation of the study. Nalidixic acid therapy with resolution of symptoms would not explain the changes seen after zinc supplementation as specific treatment was offered to both groups of patients. Zinc supplementation failed to show any effect on enteric protein loss in shigellosis since a similar, but steadily decreasing, faecal clearance of $\alpha_{1}$ antitrypsin was observed in both groups. The changes were more marked, however, in those supplemented. The clearance values did not attain normal levels even after recovery at one month, suggesting that the mucosal damage caused by the Shigella group of organisms and the protein-losing enteropathy might continue even after apparent clinical recovery. ${ }^{3}$ There was a significant negative relationship between nitrogen absorption and faecal clearance of $\alpha_{1}$ antitrypsin, suggesting a decreased antitrypsin clearance with increased nitrogen absorption in the supplemented group. This further indicates that estimation of one parameter cannot act as a proxy indicator for another.

The present study clearly show that independent of gut transit time, zinc improves the absorption of nitrogen early in the course of shigellosis when the patient remains anorectic and there is derangement of serum protein homeostasis. This effect of zinc may be highly beneficial to young children with the illness whose dietary protein intake is marginal or inadequate in the presence of an increased protein requirement and severe protein loss in the stool. Our study has failed to show any significant difference on height and weight gain in the supplemented children but the importance of long term elemental supplementation to attain such an effect cannot possibly be ruled out.

Watery diarrhoea frequently precedes the dysenteric symptoms in acute shigellosis. Shiga toxin has been shown to cause fluid production in rabbit ileal loops. ${ }^{22}$ Mobassaleh et al ${ }^{23}$ have shown evidence for a glycolipid receptor for shigella toxin involved in the fluid secretory response in rabbit small intestines. Small bowel involvement in shigellosis has been best demonstrated in the rhesus monkey model ${ }^{24}$ where the organisms proliferate first in the proximal small bowel lumen and cause a local 
secretory diarrhoea without invading the bowel mucosa. Jejunal transport abnormalities observed in the experimental animals with the disease could not be attributed to the enterotoxin mediated process alone. Evidence for similar changes in human small bowel are not definitive. The present study also raises the possibility of small intestinal mucosal changes associated with enteropathy ${ }^{25}$ in shigellosis, although this is considered to be primarily a colonic disorder.

This study was funded by the United States Agency for International Development (USAID) under grant no DPE 5986-A-00-1009-00 with the International Centre for Diarrhoeal disease Research, Bangladesh (ICDDR,B). The ICDDR,B is supported by the aid agencies of the Governments of Australia, Bangladesh, Beloium, Canada, Denmark, Japan, the Netherlands, Norway, Saudi Arabia, Sweden, Switzerland, the Netherlands, Norway, Saudi Arabia, Sweden, Switzerland, the UK and the USA; international organisations including the United Nations Children's Fund, the United Nation Development Programme, the United Nations Population Fund (UNFPA) and the World Health Organization; and private foundations including the Ford Foundation and the Sasakawa Foundation.

We thank the staff of the study ward of the Clinical Research Centre for their active support in carrying out the study and also Mr Meer Md Ramzan Ali for secretarial work.

1 Rahaman MM, Wahed MA. Direct nutrient loss and diarrhoea. In: Chen LC, Scrimshaw NS, eds. Diarrhea
and malnutrition interactions, mechanisms, and interventions. and malnutrition interactions, mechanism

2 Speelman P, Kabir I, Islam M. Distribution and spread of colonic lesions in shigellosis: a colonoscopic study. $\mathcal{F}$ Infect Dis 1984; 150: 899-903.

3 Sarker SA, Wahed MA, Rahaman MM, Alam AN, Islam A, Jahan F. Persistent protein losing enteropathy in post measles diarrhoea. Arch Dis Child 1986; 61: 739-43.

4 Molla A, Molla AM, Sarker SA, Khatoon M, Rahaman MM. Effects of acute diarrhea on absorption of macronutrients during disease and after recovery. In: Chen LC, Scrimshaw NS, eds. Diarrhea and malnutrition: interacScrimshaw NS, eds. Diarrhea and malnutrition: interac1983, mechanis 143-54.

5 Ford RPK, Menzies IS, Phillips AD, Walker-Smith JA Turner MW. Intestinal sugar permeability: relationship to diarrhoeal disease and small bowel morphology. $\mathcal{f}$ Pediatr Gastroenterol Nutr 1985; 4: 568-74.

6 Roy SK, Behrens RH, Haider R, Akramuzzaman SM, Mahalanabis D, Wahed MA, et al. Impact of zinc supplementation on intestinal permeability in Bangladeshi children with acute diarrhoea and persistent syndrome. $f$ Pediatr Gastroenterol Nutr 1992; 15: 289-96.
7 Castillo-Duran C, Vial P, Uauy R. Trace mineral balance during acute diarrhea in infants. $\mathcal{F}$ Pediatr 1988; 113: 452-7.

8 Rodriguez A, Soto G, Torres S, Venegas G, Castillo-Duran C. Zinc and copper in hair and plasma of children with chronic diarrhea. Acta Paediatr Scand 1985; 74: $770-4$.

9 Sachdev HPS, Mittal NK, Yadav HS. Serum and rectal mucosal zinc levels in acute and chronic diarrhea. Indian Pediatr 1990; 27: 125-33.

10 Hossain MA, Albert MJ. Effect of duration of diarrhoea and predictive values of stool leucocytes and red blood cells in the isolation of different serogroups or serotypes of Shigella. Trans R Soc Trop Med Hyg 1991; 85: 664-6.

11 Rahaman MM, Alam AKMJ, Islam MR, Greenough WB III, Lindenbaum J. Shiga bacillus dysentery associated with marked leukocytosis and erythrocyte fragmentation. with marked leukocytosis and erythrocy

12 Ewing WH. Edwards and Ewing's identification of Enterobacteriaceae. 4th ed. New York: Elsevier, 1986.

13 Behrens RH, Lunn PG, Northrup CA, Hanlon PW, Neale $\mathrm{G}$. Factors affecting the integrity of the intestinal mucosa of Gambian children. Am $\mathcal{F}$ Clin Nutr 1987; 45: 1433-41.

14 Seaton B, Ali A. Simplified manual high performance clinical chemistry methods for developing countries. Med Lab Sci 1984; 41: 327-36.

15 Bessey O, Lowry OH, Brock MJ. Method for rapid determination of alkaline phosphatase with 5 cubic millimeters of serum. F Biol Chem 1946; 164: 321-29.

16 Smith JC, Jr, Butrimovitz GP, Purdy WC. Direct measurement of zinc in plasma by atomic absorption measurement of zinc in plasma by atomic

17 Crossley JR, Elliott RB. Simple method for diagnosing protein-losing enteropathics. BMF 1977; 1: 428-9.

18 Henry RJ. Clinical chemistry: principles and technics. New York: Harper \& Row, 1964.

19 Rothbaum RJ, Philip RM, Farrell MK. Serum alkaline phosphatase and zinc undernutrition in infants with chronic diarrhoea. Am F Clin Nutr 1982; 35: 595-8.

20 Hill RE, Hercz A, Corey ML, Gilday DL, Hamilton JR. Fecal clearance of $\alpha_{1}$-antitrypsin: a reliable measure of enteric protein loss in children. $\mathcal{F}$ Pediatr 1981 ; 99: 416-8.

21 Prasad AS. The role of zinc in gastrointestinal and liver disease. Clin Gastroenterol 1983; 12: 713-41.

22 Keusch GT, Grady GF, Takeuchi A, Sprinz H. The pathogenesis of shigella diarrhea. II. Enterotoxin-induced acute enteritis in the rabbit ileum. I Infect Dis 1972; 126: 92-5.

23 Mobassaleh M, Donohue-Rolfe A, Jacewicz M, Grand RI, Keusch GT. Pathogenesis of shigella diarrhea. XIII. Evidence for a developmentally regulated glycolipid receptor for shigella toxin involved in the fluid secretory response of rabbit small intestine. $\mathcal{F}$ Infect Dis 1988; 157; 1023-31.

24 Rout WR, Formal SB, Giannella RA, Dammin GJ. Pathophysiology of shigella diarrhea in the rhesus monkey: intestinal transport, morphological and bacteriological studies. Gastroenterology 1975; 68: 270-8.

25 Butler T, Speelman P, Kabir I, Banwell J. Colonic dysfunction during shigellosis. F Infect Dis 1986; 154: 817-24. 